\title{
Amino Acid Composition of Protein-Enriched Dried Pasta: Is It Suitable for a Low-Carbohydrate Diet?
}

\author{
Sebastjan Filip* and Rajko Vidrih \\ Department of Food Science and Technology, Biotechnical Faculty, University of Ljubljana, \\ Jamnikarjeva 101, SI-1000 Ljubljana, Slovenia \\ Received: December 10, 2014 \\ Accepted: April 10, 2015
}

\begin{abstract}
Summary
Today, obesity is one of the major health problems, a so-called epidemic of the developed world. Obesity arises through an imbalance between energy intake and energy expenditure, so it is important for products to have a balanced nutritional composition. The aim of this study is to prepare high-protein pasta with high nutritional quality, with emphasis on its amino acid composition, as ordinary durum pasta lacks lysine and threonine. Ordinary durum wheat pasta contains, on average, $77 \%$ carbohydrate, and can have even less than $10 \%$ protein. It is therefore often excluded from normal energy-restricted diets, and especially from low-carbohydrate diets. In this study pasta that can satisfy the nutritional requirements of a low-carbohydrate diet and is suitable for daily use was developed and evaluated. Protein-enhanced pasta was produced by adding high amounts of plant protein extract (40\% dry matter) without (plain high-protein pasta) or with $3 \%$ dried spinach powder (high-protein spinach pasta) to durum wheat semolina. According to the sensory analysis data, the addition of $40 \%$ of plant protein extract satisfied sensory and nutritional requirements, allowing further development and evaluation for possible marketing. This analysis shows that these high-protein neutral and spinach pasta contain 36.4 and $39.6 \mathrm{~g}$ of protein per $100 \mathrm{~g}$ of dry mass, 12.07 and $14.70 \mathrm{~g}$ of total essential amino acids per $100 \mathrm{~g}$ of dry mass, and a high content of branched-chain amino acids, i.e. 5.54 and $6.65 \mathrm{~g}$ per $100 \mathrm{~g}$ of dry mass, respectively. This therefore represents a true alternative to durum wheat pasta for low-carbohydrate diets.
\end{abstract}

Key words: plant protein extract, high-protein food, pasta, body mass, low-carbohydrate diet, obesity

\section{Introduction}

The word 'pasta' is the Italian for 'dough', which is a stable food product that is produced mainly by mixing durum wheat semolina and water, and which is then shaped and dried (1). The main reason for the more recent huge spread of different pasta types is an awareness of consumers about nutrition, with relation to good health and an overall healthy lifestyle $(1,2)$. Pasta is usually considered a healthy food when fortified with fibre, and less commonly, it is associated with a high content of minerals, such as calcium. It is also associated with some antioxidants, like lycopene and rosemary extracts (e.g. with the addition of dried tomato and rosemary), although rarely as a protein-enriched food.

In previous studies attempts to use soya proteins as a partial substitute in wheat products because of their nutritional quality have generally been unsuccessful (3), mainly due to the contrasting differences between the soya and gluten proteins. Therefore, many studies have reported the properties of adding supplements to semolina, like chickpeas (Cicer arietinum) (4), processed lupin and pigeon pea flour (5), sweet potato (6), wheat or broad beans (Vicia faba) $(7,8)$, dried amaranth leaf flour (9) or protein hydrolysate from beans (Phaseolus vulgaris L.) 
(10), to improve the nutritional value of pasta. The interest for the enrichment of pasta with legumes has also been studied, because of their effects on the glycaemic index (11), and it has been shown that the addition of high levels of legume flour induces minor structural changes to the pasta. Consumers today are increasingly interested in foods with health-promoting ingredients $(12,13)$ and food with nutrition and/or health claims on their labels, which are designed to offer useful information to the consumer about the health benefits of a product, while current legislation protects consumers from misleading and false information (13-15).

According to European Union (EU) legislation (14, 16), high-protein products such as pasta can be declared as a 'source of protein' when the energy value provided by protein contained in that food is at least $12 \%$, or as having a 'high content of protein' when at least $20 \%$ of the energy value of the food is provided by protein. As demonstrated by Vozzo et al. (17), pre-loaded foods rich in protein, as compared to carbohydrate or fat, produce a greater feeling of satiety and reduce food intake after a fixed time interval. When eating equal amounts of calories in the same food system, foods with higher protein levels produce greater sensory-specific satiety than low-protein foods. Until recently, the marketing for such products was targeting active athletes, but now a wide range of consumers purchase nutrition bars regularly, not only to satisfy immediate hunger, but also because they are perceived as a source of nutrients or as a healthy 'to-go' meal. Higher-protein food systems also reduce hunger greatly (18) and beneficially affect cognition and mood compared to conventional food versions (19).

In the present study, the main aim is to create a protein-enriched pasta product that has real potential to be sold on the market and therefore to offer consumers a high-protein product of plant origin, with emphasis on the amino acid composition, which is essential information for the intensive workout population $(17,20)$. We were further interested to determine the amino acid composition and sensory characteristics of the pasta that is enriched with yellow pea protein isolate.

\section{Materials and Methods}

\section{Sample preparation}

High-protein pasta was produced by the addition of high amounts (40\%, dry matter) of plant protein extract (pea protein isolate, extracted from yellow peas; supplied by Cosucra, Pecq, Belgium) to durum wheat semolina (durum wheat semolina type 900, from an industrial flourmill; Farina-Mühle, Raaba, Austria) without and with $3 \%$ dry spinach powder, to provide high-protein pasta and high-protein spinach pasta, respectively.

The production of these types of high-protein pasta required adaptation of the pasta-making process (i.e. higher hydration) to limit the agglomeration of particles during mixing. The kneading and shaping were accomplished using a Dolly 4 pilot kneading machine (Granitto Arredi Srl, Termoli, Italy) with a single screw extrusion, using the 'tagliatelle' bronze die $(0.9 \mathrm{~mm}$ thick, $5.0 \mathrm{~mm}$ wide) with a capacity of $6 \mathrm{~kg}$ pasta per h. The drying process was carried out at an industrial facility, using a standard drying programme of 15 cycles on a static drier. The drying protocol consisted of exchanging cycles of drying and conditioning, starting at $70{ }^{\circ} \mathrm{C}$ and $80 \%$ humidity. To avoid any effects of drying on the pasta quality, all of the prepared samples were dried under the same drying protocol. After drying, the pasta was packed into waterproof packaging, labelled, and stored until analysis. To achieve better cooking and to ensure wide and easy use of the pasta, we produced it in the tagliatelle form.

Reference values for durum pasta (as semolina from Triticum durum) were taken from the Danish DTU National Food Institute, Danish Food Composition Databank 7.01 (Søborg, Denmark). The reference values for macronutrients were as follows: protein $(9.2 \pm 1.1) \mathrm{g}$ per $100 \mathrm{~g}$, total fat $(1.2 \pm 0.5)$ g per $100 \mathrm{~g}$, and carbohydrates $(77.7 \pm 2.2)$ $\mathrm{g}$ per $100 \mathrm{~g}$ of dry mass (dm) of durum pasta. The energy value in kilojoules $(\mathrm{kJ})$ was calculated from the contents of the protein, fat, available carbohydrate, dietary fibre, and alcohol, using the energy factors of $17,37,17,8$ and $29 \mathrm{~kJ} / \mathrm{g}$, respectively.

\section{Sensory analysis}

The enriched pasta products were cooked in hot water $(1.0 \mathrm{~L}$ of boiling water per each $100 \mathrm{~g}$ of sample) for the adequate preparation time, drained and served for sensory analysis. This was carried out by a semi-trained panel of eight members (26-39 years old, gender distribution $50 / 50)$ who were familiar with the definitions and references used to evaluate products for taste, flavour, consistency, appearance and overall quality. Tagliatelle pasta from $100 \%$ durum wheat semolina was taken as the reference value for the quality. Taste was indicated as good, which should be pleasant, without any strange aftertaste. Flavour was described by the intensity of the aroma and the specific beany off-flavour without an unpleasant smell. The consistency should be stable, uniform, soft, firm and chewy for a good score. Good appearance was defined as the surface property, which indicates the absence of cracks and roughness, and a uniform characteristic colour of the raw materials used. The overall quality of each sample was rated on a 9-point hedonic scale, and these ratings were converted into numerical scores from 1 , meaning dislike extremely to 9 , like extremely. The pasta products were considered acceptable for further analysis if their mean scores for overall quality were $>5$ and the protein content exceeded $35 \mathrm{~g}$ per $100 \mathrm{~g}$ of dried pasta.

\section{Macronutrient determination}

Moisture, fat, protein, ash and total carbohydrate contents were determined in triplicate using standard methods reported by AOAC (21) and the content of dietary fibre according to AOAC method 985.29 (22). The protein content was calculated from that of nitrogen using the factor of 6.25 for vegetable protein and 5.70 for wheat protein, as reported by Islas-Rubio (1). The carbohydrate and energy values were calculated according to MP 0297 rev 5. 2014 (23), and sugar composition according to AACC method 80-04.01 (24) using HPLC/mass spectrometry. 


\section{Amino acid analysis}

The amino acid composition of durum pasta was determined according to MP 1471 rev 52011 (25) (using ion-exchange chromatography with post-column ninhydrin detection), with tryptophan determined according to AOAC method 988.15-1988 (26). The analysed samples were hydrolysed with $4.2 \mathrm{M}$ sodium hydroxide, under a nitrogen atmosphere, for $20 \mathrm{~h}$ at $110{ }^{\circ} \mathrm{C}$. The amino acids obtained in the hydrolysate were separated and quantitatively determined using ion-exchange chromatography, with an automatic analyser $(27,28)$.

\section{Fatty acid content}

The fatty acid composition of durum pasta was determined using gas chromatography with a flame-ionisation detector, as reported by Vidrih et al. (29).

\section{Statistical methods}

The data were evaluated using the analysis of variance (ANOVA) method with Duncan's multiple-range test $(\mathrm{p}<0.05)$ of the SAS/SAT software program $(30)$.

\section{Results}

The results of the preliminary sensory and protein content analyses showed that the addition of 20 or $30 \%$ of protein did not reach the required protein content, while the addition of $50 \%$ of protein resulted in an unpleasant off-flavour. The results of the sensory analysis during the preliminary sample preparation are given in Table 1.

According to the World Health Organization/Food and Agriculture Organization of the United Nations (WHO/FAO), and organisations in Europe, the USA and Canada, the daily energy intake from protein should be from at least 10 up to $35 \%(31,32)$. Most of these recommendations are the same or similar worldwide, except for protein, which are expressed differently, either as g per day or $\mathrm{g}$ per $\mathrm{kg}$ of body mass (bm) per day, and usually without any indication of a standard for each age, which would allow conversion from one such recommendation to another. The Joint FAO/WHO/United Nations University Expert Consultation of 1985 (32) defined the protein requirement of an individual as the lowest level of dietary protein intake that will compensate for the losses of nitro- gen from the body in persons maintaining an energy balance at modest levels of physical activity.

Unequal losses of nutrients are due to their solubility in water or fat. Pasta absorbs water during cooking, whereby the mass fractions of the nutrients can decrease to approximately half their initial levels, except for the alimentary fibre, due to a larger loss of the soluble fibre. However, the energy ratio of the different nutrients does not usually change significantly. Due to some degree of unequal nutrient loss, analyses were carried out on both the dry pasta and the cooked product. The composition and nutritional parameters of the dry and cooked plain and spinach-containing high-protein pasta are given in Table 2.

The results of this analysis show that the plain high-protein pasta contains $36.4 \mathrm{~g}$ of protein per $100 \mathrm{~g}$ of $\mathrm{dm}$, and the high-protein spinach pasta $39.6 \mathrm{~g}$ per $100 \mathrm{~g}$ of $\mathrm{dm}$, which is approx. 4-fold more than in ordinary durum wheat pasta, which contains 8 to $10 \mathrm{~g}$ of protein per $100 \mathrm{~g}$ of $\mathrm{dm}$ (1). Both of our pasta samples contained $<4 \mathrm{~g}$ of fat per $100 \mathrm{~g}$ of $\mathrm{dm}$. According to the nutritional recommendations for protein intake ( $0.8 \mathrm{~g}$ per $\mathrm{kg}$ of bm per day), one portion (100 $\mathrm{g}$ of dry product) of cooked high-protein spinach pasta without any additions represents $66 \%$ of the daily protein requirement for a $75-\mathrm{kg}$ male.

It is well known that short-term diets with protein pasta can diminish cardiovascular risk factors, through increased mass loss and reduced body fat. Indeed, epidemiological studies have confirmed an inverse association between dietary protein and hypertension, as well as beneficial changes in people with type 2 diabetes (33). On the one hand, it is quite common that people with diabetes $\mathrm{A}$ (type 2) partially exclude durum pasta from their diet, or replace it with wholegrain products. On the other hand, the use of a high-protein and low-carbohydrate diet has beneficial effects on postprandial blood glucose levels, which is very important for people with diabetes A. Therefore, there is a good opportunity for high-protein pasta like plain high-protein and high-protein spinach pasta with a protein content of more than 36 and $39 \%$ respectively, to be included as a breakfast; indeed, in Asian countries like Vietnam, Cambodia, Laos, Thailand and others, noodle soup is a typical breakfast dish.

The content of some amino acids that are considered as essential in the human diet can be low in wheat proteins, especially lysine (the most deficient of the amino

Table 1. Results of the sensory analysis and protein content of samples

\begin{tabular}{ccccccc}
\hline Sample & Taste & Flavour & Consistency & Appearance & Overall quality & $\begin{array}{c}w(\text { protein) } \\
\text { g per 100 g of dm }\end{array}$ \\
\hline Ref & $(4.63 \pm 0.52)^{\mathrm{a}}$ & $(4.75 \pm 0.46)^{\mathrm{a}}$ & $(4.75 \pm 0.43)^{\mathrm{a}}$ & $(5.00 \pm 0.00)^{\mathrm{a}}$ & $(8.75 \pm 0.43)^{\mathrm{a}}$ & $(14.63 \pm 0.64)^{\mathrm{e}}$ \\
$20 \%$ & $(4.38 \pm 0.74)^{\mathrm{a}}$ & $(4.38 \pm 0.52)^{\mathrm{a}}$ & $(4.25 \pm 0.71)^{\mathrm{a}}$ & $(4.75 \pm 0.46)^{\mathrm{ab}}$ & $(7.75 \pm 1.16)^{\mathrm{ab}}$ & $(26.72 \pm 0.01)^{\mathrm{d}}$ \\
$30 \%$ & $(4.13 \pm 0.64)^{\mathrm{a}}$ & $(4.25 \pm 0.46)^{\mathrm{a}}$ & $(4.38 \pm 0.52)^{\mathrm{a}}$ & $(4.38 \pm 0.52)^{\mathrm{b}}$ & $(7.38 \pm 0.92)^{\mathrm{b}}$ & $(33.23 \pm 0.16)^{\mathrm{c}}$ \\
$40 \%$ & $(4.38 \pm 0.52)^{\mathrm{a}}$ & $(4.25 \pm 0.71)^{\mathrm{a}}$ & $(4.13 \pm 0.64)^{\mathrm{a}}$ & $(4.50 \pm 0.53)^{\mathrm{ab}}$ & $(7.75 \pm 0.89)^{\mathrm{ab}}$ & $(39.41 \pm 0.03)^{\mathrm{b}}$ \\
$50 \%$ & $(4.00 \pm 1.07)^{\mathrm{a}}$ & $(4.38 \pm 0.74)^{\mathrm{a}}$ & $(4.12 \pm 0.83)^{\mathrm{a}}$ & $(4.25 \pm 0.89)^{\mathrm{b}}$ & $(7.50 \pm 1.3)^{\mathrm{b}}$ & $(46.11 \pm 0.37)^{\mathrm{a}}$ \\
p-value & 0.475 & 0.439 & 0.294 & 0.075 & 0.069 & $<0.0001$ \\
\hline
\end{tabular}

Values with the same letter in superscript within the same column are not significantly different according to Duncan's test ( $\mathrm{p}>0.05$ ); shape of pasta: extruded tagliatelle for all samples; Ref $=100 \%$ durum wheat; $20 \%, 30 \%, 40 \%$ and $50 \%=$ samples with 20,3040 and 50

$\%$ added plant protein, respectively; $\mathrm{dm}=\mathrm{dry}$ mass 
Table 2. Composition and nutritional parameters of dry and cooked plain high-protein and high-protein spinach pasta

\begin{tabular}{|c|c|c|c|c|}
\hline \multirow{2}{*}{$\frac{w}{\text { g per } 100 \mathrm{~g} \text { of } \mathrm{dm}}$} & \multicolumn{2}{|c|}{ Plain pasta } & \multicolumn{2}{|c|}{ Spinach pasta } \\
\hline & Dry & Cooked & Dry & Cooked \\
\hline Moisture & $(8.5 \pm 0.3)^{\mathrm{b}}$ & $(58.2 \pm 0.3)^{\mathrm{a}}$ & $(8.51 \pm 0.3)^{b}$ & $(57.3 \pm 0.3)^{\mathrm{a}}$ \\
\hline Protein & $(36.4 \pm 1.8)^{\mathrm{a}}$ & $(15.6 \pm 1.1)^{\mathrm{b}}$ & $(39.6 \pm 1.9)^{\mathrm{a}}$ & $(17.2 \pm 1.1)^{\mathrm{b}}$ \\
\hline Fat & $(3.8 \pm 0.3)^{\mathrm{a}}$ & $(1.6 \pm 0.2)^{\mathrm{b}}$ & $(3.9 \pm 0.3)^{\mathrm{a}}$ & $(1.6 \pm 0.2)^{\mathrm{b}}$ \\
\hline Dietary fibre & $(4.5 \pm 0.7)^{\mathrm{a}}$ & $(1.7 \pm 0.4)^{\mathrm{b}}$ & $(5.0 \pm 0.8)^{\mathrm{a}}$ & $(1.9 \pm 0.4)^{b}$ \\
\hline Ash & $(2.1 \pm 0.1)^{\mathrm{b}}$ & $(0.90 \pm 0.05)^{\mathrm{d}}$ & $(2.5 \pm 0.1)^{\mathrm{a}}$ & $(1.10 \pm 0.06)^{c}$ \\
\hline Carbohydrate & $(44.6 \pm 1.9)^{\mathrm{a}}$ & $(21.9 \pm 1.2)^{\mathrm{b}}$ & $(40.4 \pm 2.0)^{\mathrm{a}}$ & $(20.9 \pm 1.2)^{b}$ \\
\hline Glucose & $(0.03 \pm 0.02)^{\mathrm{b}}$ & $<$ LOQ & $(0.34 \pm 0.05)^{\mathrm{a}}$ & $<$ LOQ \\
\hline Fructose & $(0.04 \pm 0.02)^{\mathrm{b}}$ & $<$ LOQ & $(0.10 \pm 0.02)^{\mathrm{a}}$ & $<$ LOQ \\
\hline Lactose & $<\mathrm{LOQ}$ & $<$ LOQ & $<$ LOQ & $<\mathrm{LOQ}$ \\
\hline Sucrose & $(0.35 \pm 0.06)^{\mathrm{a}}$ & $<\mathrm{LOQ}$ & $<$ LOQ & $(0.05 \pm 0.02)^{b}$ \\
\hline Maltose & $(1.1 \pm 0.2)^{\mathrm{a}}$ & $<\mathrm{LOQ}$ & $(0.11 \pm 0.02)^{\mathrm{c}}$ & $(0.16 \pm 0.03)^{\mathrm{b}}$ \\
\hline $\mathrm{E} /(\mathrm{kcal} / 100 \mathrm{~g})$ & $386 \pm 3$ & $168 \pm 2$ & $366 \pm 3$ & $171 \pm 2$ \\
\hline $\mathrm{E} /(\mathrm{kJ} / 100 \mathrm{~g})$ & $1557 \pm 11$ & $712 \pm 7$ & $1546 \pm 12$ & $726 \pm 8$ \\
\hline
\end{tabular}

Values with the same letter in superscript within the same row are not significantly different according to Duncan's test ( $\mathrm{p}>0.05$ );

LOQ=limit of quantification

acids in wheat) and threonine (the second most limiting amino acid in wheat) (34). In agreement with previous studies $(5,8)$, we confirmed here that the addition of plant protein (pea protein extract) to the pasta can significantly increase the content of lysine, from 0.37 to $2.07-2.50 \mathrm{~g}$ per $100 \mathrm{~g}$ of $\mathrm{dm}$, and threonine from 0.47 to $1.17-1.30 \mathrm{~g}$ per $100 \mathrm{~g}$ of $\mathrm{dm}$. Wheat protein is, on the other hand, rich in glutamic acid and proline, which are the functional amino acids in dough formation, while cysteine has an important role in dough formation, as it provides sulfhydryl groups for the disulphide bond formation that links these glutenin protein macromolecules. The total essential amino acids in the plain and spinach-containing high-protein pasta were $(12.1 \pm 0.3)$ and $(14.7 \pm 0.4) \mathrm{g}$ per $100 \mathrm{~g}$ of $\mathrm{dm}$, respectively, while ordinary durum pasta contains only 5.3 $\mathrm{g}$ of total essential amino acids per $100 \mathrm{~g}$ of $\mathrm{dm}$. The amino acid compositions of these pasta are given in Table 3.

The branched-chain amino acids (BCAAs) leucine, isoleucine and valine are indispensable amino acids. Apart from being building blocks of proteins, they also function as physiological stimulants (especially leucine) for protein synthesis and can promote anabolic effects on protein metabolism by increasing the rate of protein synthesis and decreasing the rate of protein degradation (35). BCAAs can function as pharmacological nutrients for patients with decompensated liver cirrhosis. However, the effects of BCAAs at the early stages of chronic liver disease are not clear (36).

Consumption of high amounts of BCAAs is usually associated with consumption of food supplements, rather than conventional food, and especially pasta. Nevertheless, the nitrogen balance should also be taken in consideration, at the same level that is usually included in food supplements. The protein-enriched plain and spinach-containing pasta had 3-fold more BCAAs than the conventional durum wheat pasta. Furthermore, the plain and spinach-containing high-protein pasta had leucine/valine/ isoleucine in almost the recommended ratio of 2:1:1, as reported by Scognamiglio et al. (37) and Aquilani et al. (38).
Dried pasta made from durum wheat semolina contains $<2 \mathrm{~g}$ of fat per $100 \mathrm{~g}$ of $\mathrm{dm}$, and it is therefore not an important source of fat; consequently, it is also a minor source of the fat-soluble vitamins $\mathrm{A}, \mathrm{D}, \mathrm{E}$ and $\mathrm{K}$, and the carotenoids $(29,39,40)$. Both animal- and plant-derived food products contain fat, which when consumed in moderation is important for correct growth and development, and for the maintenance of good health in general (41). The plain and spinach-containing high-protein pasta had $(3.8 \pm 0.3)$ and $(3.9 \pm 0.3) \mathrm{g}$ of fat per $100 \mathrm{~g}$ of dm respectively, which originates partly from the durum wheat and additionally from the added plant protein extract. The mass fractions of total unsaturated fatty acids were $81.5 \mathrm{~g}$ per $100 \mathrm{~g}$ of fatty acids in plain high-protein and $78 \mathrm{~g}$ per $100 \mathrm{~g}$ of total fatty acids in high-protein spinach pasta. The content of saturated fatty acids is low in both of our samples: $(18.5 \pm 0.8) \mathrm{g}$ per $100 \mathrm{~g}$ of total fatty acids in plain and $(21.9 \pm 1.1) \mathrm{g}$ per $100 \mathrm{~g}$ of total fatty acids in high-protein spinach pasta. Therefore, the unsaturated to saturated fatty acid ratio is $4: 1$, while PUFA/SFA ratio is near 3 . Recommended ratio is at least 0.45 , while for red meat it is around 0.1 (42). The fatty acid compositions of the plain and high-protein spinach pasta are in agreement with other studies that have investigated the fatty acid composition of vegetables and vegetable extracts (29), and the data obtained in the present study are given in Table 4.

Reducing the excess body mass and fat mass can be achieved successfully by restricting the energy intake, which should be supported by the balanced macronutrient composition of the diet. On this basis, low-carbohydrate energy-restricted diets have been suggested to be successful compared to normal or higher carbohydrate intake (43-45). Obviously, in these energy-restricted diets the energy ratio from carbohydrate is decreased and the energy ratio from the protein and fat is increased (46). Diets that are known as relatively high-protein energy-restricted diets have a protein energy ratio of 20 to $30 \%$ 
Table 3. Amino acid composition of the dry and cooked plain high-protein and high-protein spinach pasta

\begin{tabular}{|c|c|c|c|c|c|}
\hline \multirow{2}{*}{$\frac{w(\text { amino acid })}{\mathrm{g} \text { per } 100 \mathrm{~g}}$} & \multicolumn{2}{|c|}{ Plain pasta } & \multicolumn{2}{|c|}{ Spinach pasta } & \multirow{2}{*}{$\begin{array}{l}\text { Durum } \\
\text { wheat }\end{array}$} \\
\hline & Dry & Cooked & Dry & Cooked & \\
\hline Tryptophan* & $(0.32 \pm 0.03)^{\mathrm{a}}$ & $(0.15 \pm 0.02)^{\mathrm{c}}$ & $(0.32 \pm 0.03)^{\mathrm{a}}$ & $(0.15 \pm 0.02)^{c}$ & $0.20^{\mathrm{b}}$ \\
\hline Cysteine & $(0.35 \pm 0.04)^{\mathrm{a}}$ & $(0.17 \pm 0.02)^{\mathrm{b}}$ & $(0.35 \pm 0.04)^{\mathrm{a}}$ & $(0.17 \pm 0.02)^{\mathrm{b}}$ & $0.33^{\mathrm{a}}$ \\
\hline Methionine & $(0.37 \pm 0.04)^{\mathrm{a}}$ & $(0.18 \pm 0.02)^{\mathrm{c}}$ & $(0.36 \pm 0.04)^{\mathrm{a}}$ & $(0.17 \pm 0.02)^{\mathrm{c}}$ & $0.23^{b}$ \\
\hline Aspartic acid & $(3.1 \pm 0.4)^{\mathrm{a}}$ & $(1.6 \pm 0.2)^{\mathrm{b}}$ & $(3.7 \pm 0.4)^{\mathrm{a}}$ & $(1.69 \pm 0.02)^{\mathrm{b}}$ & $0.72^{\mathrm{c}}$ \\
\hline Threonine ${ }^{*}$ & $(1.2 \pm 0.1)^{\mathrm{a}}$ & $(0.57 \pm 0.07)^{\mathrm{c}}$ & $(1.3 \pm 0.2)^{\mathrm{a}}$ & $(0.71 \pm 0.09)^{\mathrm{b}}$ & $0.47^{c}$ \\
\hline Serine & $(1.7 \pm 0.2)^{\mathrm{a}}$ & $(0.82 \pm 0.09)^{\mathrm{b}}$ & $(1.9 \pm 0.2)^{\mathrm{a}}$ & $(0.9 \pm 0.1)^{\mathrm{b}}$ & $0.72^{\mathrm{c}}$ \\
\hline Glutamic acid & $(6.9 \pm 0.8)^{\mathrm{a}}$ & $(3.3 \pm 0.4)^{c}$ & $(7.8 \pm 0.9)^{\mathrm{a}}$ & $(3.6 \pm 0.4)^{c}$ & $5.30^{\mathrm{b}}$ \\
\hline Proline & $(2.2 \pm 0.3)^{\mathrm{a}}$ & $(1.0 \pm 0.1)^{\mathrm{b}}$ & $(2.4 \pm 0.3)^{\mathrm{a}}$ & $(1.1 \pm 0.1)^{\mathrm{b}}$ & $1.40^{\mathrm{b}}$ \\
\hline Glycine & $(1.2 \pm 0.2)^{\mathrm{a}}$ & $(0.61 \pm 0.07)^{\mathrm{b}}$ & $(1.5 \pm 0.2)^{\mathrm{a}}$ & $(0.67 \pm 0.08)^{\mathrm{b}}$ & $0.56^{\mathrm{b}}$ \\
\hline Alanine & $(1.3 \pm 0.2)^{a}$ & $(0.64 \pm 0.08)^{b}$ & $(1.5 \pm 0.2)^{\mathrm{a}}$ & $(0.70 \pm 0.08)^{\mathfrak{b}}$ & $0.50^{c}$ \\
\hline Valine & $(1.6 \pm 0.2)^{\mathrm{a}}$ & $(0.81 \pm 0.09)^{\mathrm{b}}$ & $(1.9 \pm 0.2)^{\mathrm{a}}$ & $(0.9 \pm 0.1)^{\mathrm{b}}$ & $0.69^{c}$ \\
\hline Isoleucine $e^{*}$ & $(1.4 \pm 0.2)^{\mathrm{a}}$ & $(0.72 \pm 0.09)^{\mathrm{b}}$ & $(1.7 \pm 0.2)^{\mathrm{a}}$ & $(0.78 \pm 0.09)^{\mathrm{b}}$ & $0.41^{c}$ \\
\hline Leucine* & $(2.6 \pm 0.3)^{\mathrm{a}}$ & $(1.3 \pm 0.2)^{\mathrm{b}}$ & $(3.1 \pm 0.4)^{\mathrm{a}}$ & $(1.4 \pm 0.2)^{\mathrm{b}}$ & $1.10^{\mathrm{b}}$ \\
\hline Tyrosine & $(0.95 \pm 0.1)^{\mathrm{a}}$ & $(0.51 \pm 0.06)^{b}$ & $(1.1 \pm 0.1)^{\mathrm{a}}$ & $(0.50 \pm 0.06)^{\mathrm{b}}$ & $0.45^{\mathrm{b}}$ \\
\hline Phenylalanine* & $(1.8 \pm 0.2)^{\mathrm{a}}$ & $(0.9 \pm 0.1)^{\mathrm{b}}$ & $(2.1 \pm 0.3)^{\mathrm{a}}$ & $(1.0 \pm 0.1)^{\mathrm{b}}$ & $0.69^{c}$ \\
\hline Lysine* & $(2.1 \pm 0.2)^{\mathrm{a}}$ & $(1.1 \pm 0.1)^{\mathrm{b}}$ & $(2.5 \pm 0.3)^{\mathrm{a}}$ & $(1.1 \pm 0.1)^{\mathrm{b}}$ & $0.37^{c}$ \\
\hline Histidine* & $(0.78 \pm 0.09)^{\mathrm{a}}$ & $(0.39 \pm 0.05)^{\mathrm{b}}$ & $(0.9 \pm 0.1)^{\mathrm{a}}$ & $(0.42 \pm 0.05)^{\mathrm{b}}$ & $0.36^{c}$ \\
\hline Arginine & $(2.6 \pm 0.3)^{\mathrm{a}}$ & $(1.3 \pm 0.2)^{b}$ & $(3.1 \pm 0.4)^{\mathrm{a}}$ & $(1.4 \pm 0.2)^{b}$ & $0.67^{c}$ \\
\hline Total BCAA & $(5.5 \pm 0.3)^{b}$ & $(2.8 \pm 0.2)^{\mathrm{d}}$ & $(6.6 \pm 0.4)^{a}$ & $(3.1 \pm 0.2)^{c}$ & $2.20^{\mathrm{e}}$ \\
\hline Total EAA & $(12.1 \pm 0.3)^{b}$ & $(6.1 \pm 0.1)^{c}$ & $(14.7 \pm 0.4)^{\mathrm{a}}$ & $(6.6 \pm 0.2)^{c}$ & $5.30^{\mathrm{d}}$ \\
\hline
\end{tabular}

Values with the same letter in superscript within the same row are not significantly different according to Duncan's test ( $\mathrm{p}>0.05$ ); EAA $=$ essential amino acids $\left({ }^{*}\right), \mathrm{BCAA}=$ branched-chain amino acids (in italic)

during energy restrictions of about $50 \%$, which, however, satisfies the absolute daily amount of required protein of at least $0.8 \mathrm{~g}$ per $\mathrm{kg}$ of bm (47). Such relatively high-protein diets can result in relatively large reductions in body mass and fat mass, and they support subsequent body mass maintenance, since they promote sustained satiety and energy expenditure, increased fat oxidation, and sparing of the fat-free mass $(48,49)$.

The contents of macronutrients and their nutritional qualities are as important as the ratio between them, according to nutritional guidelines (31), as indicated by the energy values of protein, total fat and carbohydrates. Plain and high-protein spinach pasta provided 41 and 45 $\%$, respectively, of the total energy from protein, while the reference durum pasta provided only $10 \%$, as shown in Fig. 1 (50). The energy from carbohydrates in the reference durum pasta was $87 \%$ of the total energy, while in the high protein samples of the plain and spinach pasta, it was 50 and $46 \%$ of the total energy, respectively. The protein content of the plain and spinach pasta followed that recommended by EU legislation $(14,16)$, and thus these types of pasta are suitable to be given the nutritional claim 'high protein content', because at least $20 \%$ of the energy value of the food is provided by protein. As reported elsewhere (51), an adequate energy requirement is the amount of energy available from food needed to balance the total energy expenditure, and hence to maintain the body mass. The total energy expenditure reflects the sum of the resting metabolic rate (60-75\%), the energy used for dietary-induced thermogenesis (approx. $10 \%$ ), and the energy expended through physical activity (15$30 \%)$. The energy used for physical activity is the most variable component here, because it depends on the lifestyle and the form of physical exercise, as well as on the gender and prior nutritional state of the subject.

There has been a considerable debate about the protein requirements of athletes who wish to increase or maintain their fat-free mass. Arguments in favour of protein needs above the dietary reference intake of $0.8 \mathrm{~g}$ per $\mathrm{kg}$ of bm per day rely on nitrogen balance studies. Retrospective analysis of nitrogen balance data suggested protein requirements of $1.1 \mathrm{~g}$ per $\mathrm{kg}$ of bm per day for athletes undergoing endurance training (52) and $1.3 \mathrm{~g}$ per $\mathrm{kg}$ of bm per day for strength-trained athletes (53). These higher needs can be explained by increased amino acid oxidation during exercise, and also growth and repair of muscle tissue.

\section{Discussion}

Reductions of excess body mass and fat mass can bring results by limiting energy intake, which should be supported by the balanced macronutrient diet. In this aspect, low-carbohydrate energy-restricted diets have been suggested as successful, compared to normal or higher carbohydrate intake, and therefore effective in body mass control $(43,49,54)$. However, these diets have higher content of protein and even fat, so consumers should avoid high-carbohydrate food such as ordinary durum pasta as 
Table 4. Fatty acid composition of dry and cooked plain high-protein and high-protein spinach pasta

\begin{tabular}{|c|c|c|c|c|}
\hline \multirow{2}{*}{$\frac{w \text { (fatty acid) }}{\text { g per } 100 \mathrm{~g}}$} & \multicolumn{2}{|c|}{ Plain pasta } & \multicolumn{2}{|c|}{ Spinach pasta } \\
\hline & Dry & Cooked & Dry & Cooked \\
\hline Butyric acid (C4:0) & n.d. & n.d. & n.d. & n.d. \\
\hline Capronic acid (C6:0) & n.d. & n.d. & n.d. & n.d. \\
\hline Enantic acid (C7:0) & n.d. & n.d. & n.d. & n.d. \\
\hline Caprilic acid (C8:0) & n.d. & n.d. & n.d. & n.d. \\
\hline Capric acid (C8:0) & n.d. & n.d. & n.d. & n.d. \\
\hline Caproleic acid (C10:1) & n.d. & n.d. & n.d. & n.d. \\
\hline Lauric acid (C12:0) & n.d. & n.d. & $(0.19 \pm 0.04)^{\mathrm{a}}$ & $(0.19 \pm 0.04)^{\mathrm{a}}$ \\
\hline Lauroleic acid (C12:1) & n.d. & n.d. & n.d. & n.d. \\
\hline Tridecanoic acid (C13:0) & n.d. & n.d. & n.d. & n.d. \\
\hline Tridecenoic acid (C13:1) & n.d. & n.d. & n.d. & n.d. \\
\hline Myristic acid (C14:0) & $(0.19 \pm 0.02)^{\mathrm{c}}$ & $(0.40 \pm 0.04)^{\mathrm{b}}$ & $(0.52 \pm 0.05)^{\mathrm{a}}$ & $(0.52 \pm 0.05)^{\mathrm{a}}$ \\
\hline Myristoleic acid (C14:1) & n.d. & n.d. & n.d. & n.d. \\
\hline Pentadecanoic acid (C15:0) & n.d. & n.d. & $(0.10 \pm 0.04)^{\mathrm{a}}$ & $(0.10 \pm 0.04)^{\mathrm{a}}$ \\
\hline Pentadecenoic acid (C15:1) & n.d. & n.d. & n.d. & n.d. \\
\hline Palmitic acid (C16:0) & $(15.1 \pm 0.8)^{b}$ & $(14.7 \pm 0.8)^{\mathrm{b}}$ & $(17.8 \pm 0.8)^{\mathrm{a}}$ & $(17.7 \pm 08)^{\mathrm{a}}$ \\
\hline Palmitoleic acid (C16:1) & $(0.45 \pm 0.05)^{\mathrm{a}}$ & $(0.22 \pm 0.04)^{\mathrm{a}}$ & $(0.54 \pm 0.05)^{\mathrm{a}}$ & $(0.54 \pm 0.05)^{\mathrm{a}}$ \\
\hline Heptadecanoic acid (C17:0) & $(0.12 \pm 0.04)^{\mathrm{a}}$ & $(0.15 \pm 0.04)^{\mathrm{a}}$ & $(0.11 \pm 0.04)^{\mathrm{a}}$ & $(0.11 \pm 0.04)^{a}$ \\
\hline Heptadecenoic acid (C17.1) & n.d. & $(0.15 \pm 0.04)^{\mathrm{a}}$ & trace & trace \\
\hline Stearic acid (C18:0) & $(2.3 \pm 0.2)^{b}$ & $(2.5 \pm 0.2)^{b}$ & $(2.8 \pm 0.2)^{\mathrm{a}}$ & $(2.8 \pm 0.2)^{\mathrm{a}}$ \\
\hline Oleic acid (C18:1) & $(22.4 \pm 0.9)^{\mathrm{b}}$ & $(22.7 \pm 0.9)^{\mathrm{b}}$ & $(35.0 \pm 1.1)^{\mathrm{a}}$ & $(35.0 \pm 1.1)^{a}$ \\
\hline Linoleic acid (C18:2) & $(52.2 \pm 1.4)^{\mathrm{a}}$ & $(51.8 \pm 1.4)^{\mathrm{a}}$ & $(37.3 \pm 1.1)^{\mathrm{b}}$ & $(37.3 \pm 1.1)^{\mathrm{b}}$ \\
\hline Linolenic acid (C18:3) & $(5.9 \pm 0.4)^{\mathrm{a}}$ & $(6.1 \pm 0.4)^{\mathrm{a}}$ & $(4.7 \pm 0.3)^{\mathrm{b}}$ & $(4.7 \pm 0.3)^{\mathrm{b}}$ \\
\hline Arachidic acid (C20:0) & $(0.32 \pm 0.04)^{\mathrm{a}}$ & $(0.47 \pm 0.05)^{\mathrm{a}}$ & $(0.42 \pm 0.05)^{\mathrm{a}}$ & $\left(0.42 \pm 0.05^{\mathrm{a}}\right.$ \\
\hline Eicosaenoic acid (C20:1) & $(0.67 \pm 0.06)^{\mathrm{a}}$ & $(0.75 \pm 0.07)^{\mathrm{a}}$ & $(0.45 \pm 0.05)^{\mathrm{b}}$ & $(0.45 \pm 0.05)^{\mathrm{b}}$ \\
\hline Docosanoic acid (C22:0) & $(0.23 \pm 0.04)^{\mathrm{a}}$ & n.d. & n.d. & n.d. \\
\hline Erucic acid (C22:1) & n.d. & n.d. & n.d. & n.d. \\
\hline Tetracosanoic acid (C24:0) & $(0.25 \pm 0.04)^{\mathrm{a}}$ & n.d. & n.d. & n.d. \\
\hline SFAs & $(18.5 \pm 0.8)^{\mathrm{b}}$ & $(18.2 \pm 0.8)^{b}$ & $(21.9 \pm 1.1)^{\mathrm{a}}$ & $(21.9 \pm 0.8)^{a}$ \\
\hline MUFAs & $(23.5 \pm 0.9)^{\mathrm{b}}$ & $(23.9 \pm 0.9)^{b}$ & $(36.0 \pm 1.1)^{\mathrm{a}}$ & $(36.0 \pm 1.1)^{\mathrm{a}}$ \\
\hline PUFAs & $(58.0 \pm 1.5)^{\mathrm{a}}$ & $(57.9 \pm 1.5)^{\mathrm{a}}$ & $(42.0 \pm 1.2)^{\mathrm{b}}$ & $(42.0 \pm 1.2)^{\mathrm{b}}$ \\
\hline
\end{tabular}

Values with the same letter in superscript within the same row are not significantly different according to Duncan's test ( $\mathrm{p}>0.05)$; SFAs=saturated fatty acids, MUFAs=monounsaturated fatty acids, PUFAs=polyunsaturated fatty acids, n.d.=not detected

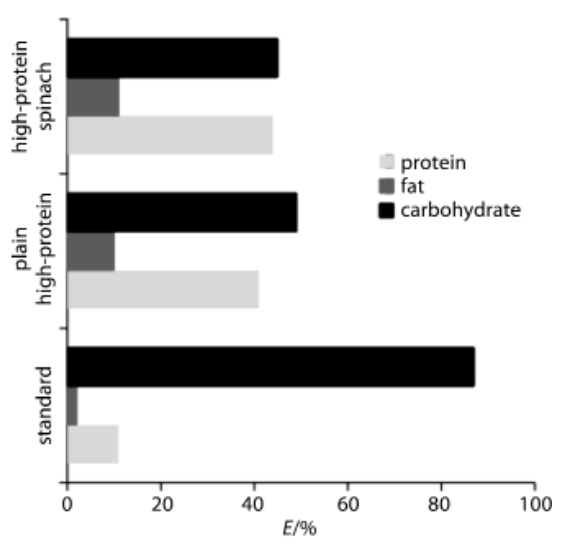

Fig. 1. Energy from the macronutrients in the plain high-protein and high-protein spinach pasta in comparison with the standard. Energy factors: $17 \mathrm{~kJ} / \mathrm{g}$ for protein, $37 \mathrm{~kJ} / \mathrm{g}$ for fat, and $17 \mathrm{~kJ} / \mathrm{g}$ for available carbohydrate (50) well as white bread, rice, noodles, potato and others. As reported by D'Anci et al. (19), the low-carbohydrate mass loss diets can affect cognition, memory performance, and mood, especially extremely low-carbohydrate diets (0-1 g of carbohydrates per day). Several studies and meta-analyses of randomised controlled trails that compared normal diets with higher-protein diets have been published, and almost all of them concluded that diets with high protein content are superior to conventional food. As these can also maintain body mass while losing fat, they are better for keeping lean body and muscle mass, and they generally have beneficial effects on the risk factors for type 2 diabetes and cardiovascular disease (55).

Data from previous studies $(56,57)$ have suggested that oral BCAA supplementation can be useful to improve protein catabolism and lipolysis in cirrhotic patients. Similar findings were reported when Kuwahata et al. (56) studied BCAA attenuation of hepatic apoptosis in 
rats with chronic liver disease. Therefore, these plain high-protein and high-protein spinach pasta might be useful if incorporated into the daily diet for patients with decompensated liver cirrhosis.

Bad nutritional habits, like overeating and lack of physical activity, usually correlate with the occurrence of nutrition-related diseases and illnesses. On the other hand, the common practice among active population, particularly athletes, is to optimise the body composition and body mass prior to a competitive season or major tournament (58). Negative energy balance is required to lose body mass. The metabolisable energy of protein is defined in the Atwater factors to be $17 \mathrm{~kJ} / \mathrm{g}$ (59); however, protein is particularly thermogenic, and its net metabolisable energy is actually $13 \mathrm{~kJ} / \mathrm{g}$, making it lower than either carbohydrate or fat, at 17 and $34 \mathrm{~kJ} / \mathrm{g}$, respectively (50). Changing the dietary habits, like reducing fat and sugar, combined with a negative energy balance, can thus give the best results.

The high-protein pasta investigated in the present study (the plain and spinach pasta) has higher protein content, with 3-fold more BCAAs, compared to ordinary durum pasta. According to the findings from other studies $(60,61)$, it is predicted that the plain and spinach pasta also have a lower glycaemic index and will provide better and longer periods of satiety.

However, even if such nutritionally balanced foods are developed and promoted through health-care institutions, this would still not prevent the consumer from overeating and becoming overweight, and even obese. As has been reported, even in the most developed countries, about half of the population is overweight (body mass index $\geq 25 \mathrm{~kg} / \mathrm{m}^{2}$ ), while about $20 \%$ are obese (55). Even though the majority of these populations have the economic means to afford healthy food, the nutrition of the major part of these populations remains unhealthy.

\section{Conclusion}

Our protein-enhanced plain and/or spinach pasta are suitable for low-carbohydrate diets in everyday nutrition because they contain half the levels of carbohydrates compared to ordinary durum pasta and they provide sufficient amounts of protein for normal nutrition, as well as 3-fold more BCAAs than ordinary durum pasta. Therefore, as part of a low-carbohydrate diet, the plain and/or spinach pasta can help maintain body mass, muscle mass and enable fat loss, and they might have an important role in the management of liver cirrhosis.

\section{Acknowledgements}

The authors would like to thank the many people involved in the study, including co-investigators, other staff, and partner organisations, and especially the Pekarna Pečjak d.o.o. company, which made it possible to carry out tests and sample preparation on their pilot equipment and allowed us the use of their developing facilities.

\section{References}

1. Islas-Rubio AR, Calderón de la Barca AM, Cabrera-Chávez F, Cota-Gastélum AG, Beta T. Effect of semolina replacement with a raw:popped amaranth flour blend on cooking quality and texture of pasta. LWT - Food Sci Technol. 2014;57:21722.

http://dx.doi.org/10.1016/j.lwt.2014.01.014

2. Foschia M, Peressini D, Sensidoni A, Brennan CS. The effects of dietary fibre addition on the quality of common cereal products. J Cereal Sci. 2013;58:216-27. http://dx.doi.org/10.1016/j.jcs.2013.05.010

3. Lamacchia C, Baiano A, Lamparelli S, Padalino L, La Notte E, Luccia AD. Study on the interactions between soy and semolina proteins during pasta making. Food Res Int. 2010; 43:1049-56. http://dx.doi.org/10.1016/j.foodres.2010.01.016

4. Wood JA. Texture, processing and organoleptic properties of chickpea-fortified spaghetti with insights to the underlying mechanisms of traditional durum pasta quality. J Cereal Sci. 2009;49:128-33. http://dx.doi.org/10.1016/j.jcs.2008.07.016

5. Martínez-Villaluenga C, Torres A, Frias J, Vidal-Valverde C. Semolina supplementation with processed lupin and pigeon pea flours improve protein quality of pasta. LWT - Food Sci Technol. 2010;43:617-22.

http://dx.doi.org/10.1016/j.lwt.2009.11.001

6. Limroongreungrat $\mathrm{K}$, Huang YW. Pasta products made from sweetpotato fortified with soy protein. LWT - Food Sci Technol. 2007;40:200-6. http://dx.doi.org/10.1016/j.lwt.2005.09.012

7. Giménez MA, Drago SR, De Greef D, Gonzalez RJ, Lobo $\mathrm{MO}$, Samman NC. Rheological, functional and nutritional properties of wheat/broad bean (Vicia faba) flour blends for pasta formulation. Food Chem. 2012;134:200-6. http://dx.doi.org/10.1016/j.foodchem.2012.02.093

8. Petitot M, Boyer L, Minier C, Micard V. Fortification of pasta with split pea and faba bean flours: Pasta processing and quality evaluation. Food Res Int. 2010;43:634-41. http://dx.doi.org/10.1016/j.foodres.2009.07.020

9. Borneo R, Aguirre A. Chemical composition, cooking quality, and consumer acceptance of pasta made with dried amaranth leaves flour. LWT - Food Sci Technol. 2008;41:1748-51. http://dx.doi.org/10.1016/j.lwt.2008.02.011

10. Segura-Campos MR, García-Rodríguez K, Ruiz-Ruiz JC, Chel-Guerrero L, Betancur-Ancona D. In vitro bioactivity, nutritional and sensory properties of semolina pasta added with hard-to-cook bean (Phaseolus vulgaris L.) protein hydrolysate. J Funct Foods. 2014;8:1-8.

http://dx.doi.org/10.1016/j.jff.2014.02.016

11. Wójtowicz A, Mościcki L. Influence of legume type and addition level on quality characteristics, texture and microstructure of enriched precooked pasta. LWT - Food Sci Technol. 2014;59:1175-85. http://dx.doi.org/10.1016/j.lwt.2014.06.010

12. Chand A, Eyles H, Ni Mhurchu C. Availability and accessibility of healthier options and nutrition information at New Zealand fast food restaurants. Appetite. 2012;58:227-33. http://dx.doi.org/10.1016/j.appet.2011.10.006

13. Komatsu TR, Buriti FCA, da Silva RC, Lobo AR, Colli C, Gioielli LA, Saad SMI. Nutrition claims for functional guava mousses produced with milk fat substitution by inulin and/ or whey protein concentrate based on heterogeneous food legislations. LWT - Food Sci Technol. 2013;50:755-65. http://dx.doi.org/10.1016/j.lwt.2012.07.013

14. Grunert KG, Scholderer J, Rogeaux M. Determinants of consumer understanding of health claims. Appetite. 2011;56: 269-77.

http://dx.doi.org/10.1016/j.appet.2011.01.009

15. Gravel K, Doucet É, Herman CP, Pomerleau S, Bourlaud AS, Provencher V. "Healthy," "diet," or "hedonic". How nutrition claims affect food-related perceptions and intake? Ap- 
petite. 2012;59:877-84.

http://dx.doi.org/10.1016/j.appet.2012.08.028

16. Gilsenan MB. Nutrition \& health claims in the European Union: A regulatory overview. Trends Food Sci Tech. 2011;22: 536-42. http://dx.doi.org/10.1016/j.tifs.2011.03.004

17. Vozzo R, Wittert G, Cocchiaro C, Tan WC, Mudge J, Fraser R, Chapman I. Similar effects of foods high in protein, carbohydrate and fat on subsequent spontaneous food intake in healthy individuals. Appetite. 2003;40:101-7. http://dx.doi.org/10.1016/S0195-6663(03)00003-5

18. Vandewater K, Vickers Z. Higher-protein foods produce greater sensory-specific satiety. Physiol Behav. 1996;59:579-83. http://dx.doi.org/10.1016/0031-9384(95)02113-2

19. D'Anci KE, Watts KL, Kanarek RB, Taylor HA. Low-carbohydrate weight-loss diets. Effects on cognition and mood. Appetite. 2009;52:96-103. http://dx.doi.org/10.1016/j.appet.2008.08.009

20. Long SJ, Jeffcoat AR, Millward DJ. Effect of habitual dietaryprotein intake on appetite and satiety. Appetite. 2000;35:7988. http://dx.doi.org/10.1006/appe.2000.0332

21. Official Methods of Analysis. Arlington, VA, USA: Association of Official Analytical Chemists (AOAC); 1995.

22. AOAC Official Method 985.29. Total dietary fiber in foods. Arlington, VA, USA: Association of Official Analytical Chemists (AOAC); first action 1985 and final action 1986.

23. Method MP 0297 rev 5. 2014. Test report. Resana, Italy: Chelab Silliker S.r.l, Mérieux NutriSciences Company; 2014 (in Italian)

24. Approved Methods of the AACC, International. St. Paul, MN, USA: American Association of Cereal Chemists (AACC); 1983.

25. Method MP 1471 rev 5 2011. Resana, Italy: Chelab Silliker S.r.l, Mérieux NutriSciences Company; 2011 (in Italian).

26. AOAC Official Method 988.15-1988. Tryptophan in foods and feed ingredients - Ion exchange chromatographic method. Arlington, VA, USA: Association of Official Analytical Chemists (AOAC); first action 1988 and final action 1990.

27. Blomstrand E, Saltin B. BCAA intake affects protein metabolism in muscle after but not during exercise in humans. Am J Physiol-Endoc M. 2001;281:E365-74.

28. Sujak A, Kotlarz A, Strobel W. Compositional and nutritional evaluation of several lupin seeds. Food Chem. 2006;98:711-9. http://dx.doi.org/10.1016/j.foodchem.2005.06.036

29. Vidrih R, Filip S, Hribar J. Content of higher fatty acids in green vegetables. Czech J Food Sci. 2009;27:S125-9.

30. SAS OnlineDoc ${ }^{\circledR}$, v. 8. SAS Institute Inc.: Cary, NC, USA; 1999.

31. Pavlovic M, Prentice A, Thorsdottir I, Wolfram G, Branca F. Challenges in harmonizing energy and nutrient recommendations in Europe. Ann Nutr Metab. 2007;51:108-14.

32. Energy and protein requirements. WHO - Techn. Report Ser. 1985;No.724.

33. Pedersen E, Jesudason DR, Clifton PM. High protein weight loss diets in obese subjects with type 2 diabetes mellitus. Nutr Metab Cardiovasc Dis. 2014;24:554-62. http://dx.doi.org/10.1016/j.numecd.2013.11.003

34. Abdel-Aal ESM, Hucl P. Amino acid composition and in vitro protein digestibility of selected ancient wheats and their end products. J Food Compos Anal. 2002;15:737-47. http://dx.doi.org/10.1006/jfca.2002.1094

35. Aquilani R, Boselli M, Boschi F, Viglio S, Iadarola P, Dossena $\mathrm{M}$, et al. Branched-chain amino acids may improve recovery from a vegetative or minimally conscious state in patients with traumatic brain injury: a pilot study. Arch Phys Med
Rehabil. 2008;89:1642-7.

http://dx.doi.org/10.1016/j.apmr.2008.02.023

36. Kawaguchi T, Shiraishi K, Ito T, Suzuki K, Koreeda C, Ohtake T, et al. Branched-chain amino acids prevent hepatocarcinogenesis and prolong survival of patients with cirrhosis. Clin Gastroenterol Hepatol. 2014;12:1012-8.e1. http://dx.doi.org/10.1016/j.cgh.2013.08.050

37. Scognamiglio R, Negut C, Piccolotto R, Dioguardi FS, Tiengo A, Avogaro A. Effects of oral amino acid supplementation on myocardial function in patients with type 2 diabetes mellitus. Am Heart J. 2004;147:1106-12. http://dx.doi.org/10.1016/j.ahj.2003.12.003

38. Aquilani R, Zuccarelli GC, Dioguardi FS, Baiardi P, Frustaglia A, Rutili C, et al. Effects of oral amino acid supplementation on long-term-care-acquired infections in elderly patients. Arch Gerontol Geriatr. 2011;52:e123-8. http://dx.doi.org/10.1016/j.archger.2010.09.005

39. Filip S, Fink R, Hribar J, Vidrih R. Trans fatty acids in food and their influence on human health. Food Technol Biotechnol. 2010;48:135-42.

40. Jan M, Filip S, Polak T, Hribar J, Vidrih R. Quantitative comparison of the fatty acid composition of dairy and artificial creams and their nutritional value in the human diet. Milchwissenschaft. 2011;66:186-9.

41. Filip S, Hribar J, Vidrih R. Influence of natural antioxidants on the formation of trans-fatty-acid isomers during heat treatment of sunflower oil. Eur J Lipid Sci Tech. 2011;113:22430.

42. Polak T, Rajar A, Gašperlin L, Žlender B. Cholesterol concentration and fatty acid profile of red deer (Cervus elaphus) meat. Meat Sci. 2008;80:864-9.

http://dx.doi.org/10.1016/j.meatsci.2008.04.005

43. Dansinger ML, Gleason JA, Griffith JL, Selker HP, Schaefer EJ. Comparison of the Atkins, Ornish, Weight Watchers, and Zone Diets for weight loss and heart disease risk reduction: A randomized trial. JAMA. 2005;293:43-53.

44. Gardner CD, Kiazand A, Alhassan S, Kim S, Stafford RS, Balise RR, et al. Comparison of the Atkins, Zone, Ornish, and LEARN diets for change in weight and related risk factors among overweight premenopausal women: the A to $\mathrm{Z}$ weight loss study: a randomized trial. JAMA. 2007;297:96977.

45. Boden G, Sargrad K, Homko C, Mozzoli M, Stein TP. Effect of a low-carbohydrate diet on appetite, blood glucose levels, and insulin resistance in obese patients with type 2 diabetes. Ann Intern Med. 2005;142:403-11.

46. Samaha FF, Iqbal N, Seshadri P, Chicano KL, Daily DA, McGrory J, et al. A low-carbohydrate as compared with a lowfat diet in severe obesity. New Engl J Med. 2003;348:2074-81.

47. Geukers VG, Li Z, Ackermans MT, Bos AP, Jinfeng L, Sauerwein HP. High-carbohydrate/low-protein-induced hyperinsulinemia does not improve protein balance in children after cardiac surgery. Nutrition. 2012;28:644-50. http://dx.doi.org/10.1016/j.nut.2011.09.018

48. Giordano M, Ciarambino T, Castellino P, Cataliotti A, Malatino L, Ferrara N, et al. Long-term effects of moderate protein diet on renal function and low-grade inflammation in older adults with type 2 and chronic kidney disease. Nutrition. 2014;30:1045-9. http://dx.doi.org/10.1016/j.nut.2014.03.007

49. Soenen S, Bonomi AG, Lemmens SGT, Scholte J, Thijssen MAMA, van Berkum F, Westerterp-Plantenga MS. Relatively high-protein or 'low-carb' energy-restricted diets for body weight loss and body weight maintenance? Physiol Behav. 2012;107:374-80.

http://dx.doi.org/10.1016/j.physbeh.2012.08.004 
50. Westerterp-Plantenga MS. Protein intake and energy balance. Regul Pept. 2008;149:67-9.

51. Genton L. Clinical Nutrition University: Calorie and macronutrient requirements for physical fitness. e-SPEN. 2011;6. e77-84. http://dx.doi.org/10.1016/j.eclnm.2011.01.008

52. Tarnopolsky M. Protein requirements for endurance athletes. Nutrition. 2004;20:662-8. http://dx.doi.org/10.1016/j.nut.2004.04.008

53. Philips N, Hwang H, Chauhan S, Leonardi D, Gonzalez S. Stimulation of cell proliferation and expression of matrixmetalloproteinase- 1 and interleukin- 8 genes in dermal fibroblasts by copper. Connect Tissue Res. 2010;51:224-9.

54. Merino J, Kones R, Ferré R, Plana N, Girona J, Aragonés G, et al. Low-carbohydrate, high-protein, high-fat diet alters small peripheral artery reactivity in metabolic syndrome patients. Clín Invest Arterioscl. 2014;26:58-65. http://dx.doi.org/10.1016/j.arteri.2013.11.004

55. Astrup A, Geiker NRW. Efficacy of higher protein diets for long-term weight control. How to assess quality of randomized controlled trials? Nutr Metab Cardiovasc Dis. 2014;24: 220-3. http://dx.doi.org/10.1016/j.numecd.2014.02.003

56. Kuwahata M, Kubota H, Kanouchi H, Ito S, Ogawa A, Kobayashi Y, Kido Y. Supplementation with branched-chain amino acids attenuates hepatic apoptosis in rats with chronic liver disease. Nutr Res. 2012;32:522-9.

http://dx.doi.org/10.1016/j.nutres.2012.06.007

57. Takeshita S, Ichikawa T, Nakao K, Miyaaki H, Shibata H, Matsuzaki T, et al. A snack enriched with oral branchedchain amino acids prevents a fall in albumin in patients with liver cirrhosis undergoing chemoembolization for hepatocellular carcinoma. Nutr Res. 2009;29:89-93. http://dx.doi.org/10.1016/j.nutres.2008.12.005

58. Juraschek SP, Appel LJ, Anderson CAM, Miller III ER. Effect of a high-protein diet on kidney function in healthy adults: results from the OmniHeart trial. Am J Kidney Dis. 2013;61: 547-54. http://dx.doi.org/10.1053/j.ajkd.2012.10.017

59. Westerterp-Plantenga MS, Lejeune MPGM. Protein intake and body-weight regulation. Appetite. 2005;45:187-90. http://dx.doi.org/10.1016/j.appet.2005.02.005

60. Simonato B, Curioni A, Pasini G. Digestibility of pasta made with three wheat types: a preliminary study. Food Chem. 2015;174:219-25. http://dx.doi.org/10.1016/j.foodchem.2014.11.023

61. Brennan CS, Symons LJ, Tudorica CM. Low GI cereal foods: the role of dietary fibre and food structure. In: Cauvain SP, Salmon SS, Young LS, editors. Using cereal science and technology for the benefit of consumers. Proceedings of the12th International ICC Cereal and Bread Congress, 24-26th May, 2004, Harrogate, UK. Sawston, UK: Woodhead Publishing; 2005. pp. 95-101. 